\title{
PROSAVANA: INSTRUMENTO DE COOPERAÇÃO INTERNACIONAL (NORTE)-SUL-SUL
}

\section{André de Paiva Toledo}

Bacharel e Mestre em Direito pela Universidade Federal de Minas Gerais (UFMG), Doutor em Direito pela Université Panthéon-Assas Paris II (Sorbonne), Professor do Programa de Pós-Graduação em Direito da Escola Superior Dom Helder Câmara.

\section{Resumo}

Diante da crise energético-alimentar de 2008, a África passa a ser vista pelas instituições internacionais como território de expansão da fronteira agrícola, isto é, local de inserção do agronegócio. Apesar das contestaçōes quanto ao caráter improdutivo do modelo tradicional de produção local, diversos Estados africanos têm estabelecido acordos internacionais de investimento com vistas à modernização de sua agricultura. Nesse contexto, surge o acordo trilateral entre Japão, Brasil e Moçambique, que possibilitará a implementação neste país do Prosavana, o programa de desenvolvimento agrícola da Savana moçambicana. Justificado como resultado da cooperação internacional Sul-Sul em contraposição ao tradicional mecanismo Norte-Sul, verificar-se-á que, na realidade, o Prosavana é um instrumento de cooperação (Norte)-Sul-Sul, pelo qual são garantidos determinados interesses incompatíveis com a horizontalidade da cooperaçáo Sul-Sul.

\section{Palavras-chave}

Prosavana; Cooperação trilateral; Cooperação (Norte)-Sul-Sul.

\section{Resumé}

Compte tenu de la crise énergétique et alimentaire de 2008, l'Afrique est considérée par les institutions internationales le territoire pour l'expansion de la frontière agricole à travers l'insertion de l'agro-industrie. Malgré les contestations concernant le caractère improductif du modèle traditionnel de production locale, plusieurs États africains ont établi des accords internationaux d'investissement pour moderniser son agriculture. Dans ce contexte, il est l'accord trilatéral entre le Japon, le Brésil et le Mozambique, qui permettra la mise en œuvre dans ce pays du Prosavana, le programme de développement agricole de la Savane mozambicaine. Justifié en raison de la coopération internationale Sud-Sud en 
contraposition du mécanisme traditionnel Nord-Sud, le Prosavana est effectivement un instrument de coopération (Nord)-Sud-Sud, par lequel certains intérêts contradictoires avec l'horizontalité de la coopération Sud-Sud sont garantis.

\section{Mots-clé}

Prosavana; Coopération trilatérale; Coopération (Nord)-Sud-Sud.

\section{Introdução}

O setor agrícola sempre foi um setor econômico estratégico. Com a revolução das biotecnologias, também conhecida por Revolução Verde, a agropecuária foi absorvida definitivamente pela lógica totalizante do capitalismo, segundo a qual todas as fases do processo produtivo até a comercialização do produto final devem ser controladas pelo homem em conformidade com critérios objetivos de maximização dos lucros. Isso significa que a produção agrícola torna-se cada vez mais um pilar fundamental para a organização interna e externa do Estado, na medida em que ela repercute em questóes vitais para a subsistência humana: a segurança alimentar e a autonomia energética.

Em momentos de crise econômica, como a que se iniciou em 2008, quando coloca-se em risco a manutenção sistêmica, a questão agrícola tende a assumir uma posição de destaque nas preocupaçôes dos Estados, visto ser ela a condição de manutenção da estrutura em movimento. É neste contexto que se destaca o incentivo internacional para que o agronegócio seja incorporado definitivamente nos processos produtivos dos Estados africanos.

Dentre as estratégias de adoção do agronegócio no continente africano, dar-se-á atenção àquela que se refere ao Programa de Cooperação Tripartida para o Desenvolvimento Agrícola da Savana Tropical em Moçambique (Prosavana), criado no âmbito do acordo trilateral de cooperação internacional existente desde 2009 entre Japão, Brasil e Moçambique.

O objetivo é demonstrar que, apesar da retórica oficial e de uma parcela importante da doutrina, que veem o Prosavana como exemplo eficiente da cooperação Sul-Sul, este programa é de fato um exemplo de um outra espécie de cooperação, que será identificada como de tipo (Norte)-Sul-Sul, pela qual os interesses de Estados desenvolvidos são representados e garantidos através de um instrumento destinado à parceria solidária e horizontal dos Estados em desenvolvimento.

Para tanto, serão examinados sucessivamente as características do agronegócio como modelo de produção agrícola capitalista, a identificação da África como local ideal para o crescimento do setor agroindustrial contemporâneo, o protagonismo de Brasil, China 
e Índia em acordos de cooperação internacional na África, a criação e implementaçâo do Prosavana em Moçambique e os respectivos objetivos de Brasil e Japão em Moçambique. Por fim, serão comparados os requisitos formais da cooperação Sul-Sul com o que existe materialmente no Prosavana para que seja concluído que tal programa deve ser considerado de outra espécie: (Norte)-Sul-Sul.

\section{A Internacionalização do Agronégocio}

Os sujeitos envolvidos no sistema cada vez mais globalizado de produção agrícola têm adotado e propagado política e ideologicamente, de maneira universal, uma lógica produtiva própria daquilo que se costuma chamar de agronegócio. Pode-se definir o conceito de agronegócio como o modelo agrícola fundado no controle total do funcionamento da cadeia produtiva de tipo industrial, que parte do fornecimento de sementes, passa pela aplicação de insumos químicos, pela produção propriamente dita, pelo processamento da matéria-prima, culminando no transporte e no comércio em mercados finais urbanos. Este modelo leva continuamente em conta, em cada fase do processo, dados objetivos de custo-benefício a fim de minimizar os custos e maximizar os lucros. O sistema do agronegócio tem permitido assim a completa mercantilização da relaçôes do homem com o alimento, consideradas os vínculos mais fundamentais que o homem pode estabelecer com o seu meio, pois surgem em concomitância com a própria vida. "A alimentação está vinculada não apenas à nutrição, mas também à troca ao contato com o outro e a toda relação de amor e carinho estabelecida entre mãe e filho." (MATURANA, 2010, p. 182)

A globalização do setor produtivo e comercial, cujo ápice pode ser identificado com o surgimento em meados da década de 1990 da Organização Mundial do Comércio (OMC), é a condição histórica material que propiciou a internacionalizaçấo das empresas, sediadas em sua grande maioria nos Estados do Norte. Muitas dessas empresas internacionalizadas já vinham, mesmo antes da criação da OMC, apostando na industrialização da agropecuária. Com a adoção paulatina do modelo do agronegócio e o fortalecimento dessas empresas, houve consequentemente o aparecimento de um grupo restrito de agentes do agronegócio com aptidáo para a inserção planetária daquele processo de produção agrícola. De fato, os acordos internacionais sobre o comércio possibilitaram o contexto jurídico necessário à liberalização formal do dumping por parte de poucas companhias agroindustriais, que passaram a dominar toda a cadeia produtiva agrícola. (OKADA, 2014, p. 19)

De forma sistemática, a ascensão global do agronegócio representou o alcance de um estágio tecnológico capaz de interferir diretamente nas ciências da vida. No momento em que uma determinada tecnologia implica na possibilidade do domínio artificial do processo vital, seja ele animal ou vegetal, está-se diante da possibilidade de inserção daquele 
objeto natural em uma lógica artificial de produção capitalista de tipo industrial. Instrumentaliza-se a própria vida e o homem vê-se como o motor da existência dos elementos da natureza. $\mathrm{O}$ aparente controle absoluto por parte do homem da dinâmica da natureza acarreta necessariamente a possibilidade de escolha dos rumos do regime alimentar global. A produção, distribuição e consumo de alimentos passam a ser resultado de escolhas estrategicamente feitas por quem detém o monopólio da respectiva tecnologia.

Diante de tal realidade, não pode causar espanto o fato de que o sistema alimentar contemporâneo está cada vez mais submetido ao investimento estrangeiro direto em associação com o pequeno grupo de companhias agroindustriais. Em especial, com o advento da atual crise econômica mundial, iniciada em 2008, em que as desigualdades econômicas se exacerbam, a presença global desses investimento tornou-se ainda mais perceptível, tendo em vista a grande volatilidade dos preços das commodities, o aumento da produção dos biocombustíveis diante da alta do petróleo, a especulação imobiliária, o aumento do consumo internacional de carne, os constantes desequilíbrios climáticos e o número cada vez maior de habitantes no Planeta. (OKADA, 2014, p. 1) Nem todos perdem com as crises econômicas. Ao contrário, o que se vê é um processo de concentração de renda em períodos de desequilíbrio financeiro. Como retrato deste fenômeno, cita-se que "[...] a crise financeira detonada em setembro de 2008 veio a calhar para os mais ricos. O 1\% do topo da pirâmide, anota a pesquisa, detém hoje metade da riqueza gerada no planeta." (CINTRA, 2014)

\section{3. África como Locus de Enfrentamento da Crise de 2008}

Diante desse quadro de desequilíbrios econômicos, demográficos e climáticos, a Organização das Naçôes Unidas para a Agricultura e Alimentação (FAO) e o Banco Mundial publicaram, em 2009, uma pesquisa intitulada Awakening Africa's Sleeping Giant: Prospects for Commercial Agriculture in the Guinea Savannah Zone and Beyond, segundo a qual, a região da Savana da Guiné, onde se localizam 25 Estados nacionais, teria um potencial agrícola representado por 400 milhóes de hectares agricultáveis, sendo que só $10 \%$ estariam sendo de fato explorados. Ademais, o mesmo estudo indicou que o modelo de exploração agrícola adotado no Cerrado brasileiro nas últimas décadas deveria ser utilizado como o exemplo a ser seguido na África. A publicação das instituiçôes internacionais chega a mencionar expressamente a possibilidade de exploraçáo na Savana de produtos que se adaptaram muito bem ao ecossistema brasileiro, como é o caso da mandioca, do algodão, do milho, do arroz, da soja e da cana-de-açúcar. (SCHLESINGER, 2013, p. 16)

Em 2011, o mesmo Banco Mundial insistia em demonstrar a crescente demanda global por terras agricultáveis e a respectiva disponibilidade fundiária na África subsaariana. Nesse contexto de excesso de procura e a constataçáo da existência de subutilizaçáo 
agrícola na África, Moçambique passa a ser visto como o Estado onde deveriam preferencialmente desembarcar os investimentos estrangeiros diretos. Ele passar paulatinamente a ser visto como território suscetível de ser apropriado, em vista do aumento da produtividade agrícola por meio do uso intensivo de biotecnologia. Outro fator importante que tem despertado o interesse dos representantes do agronegócio é o baixíssimo preço da terra na África subsaariana em comparação com aqueles cobrados em outras fronteiras agrícolas, como é o caso do Brasil. Além disso, as vantagens oferecidas pelo governo local, quando da negociaçấo dos contratos de acesso à terra, têm sido outro atrativo para os investimentos estrangeiros. No caso específico de Moçambique, por exemplo, o governo não tem medido esforços para fornecer a investidores estrangeiros terras e condiçóes jurídicas (ambientais, trabalhistas, tributárias) para a implementação em seu território do sistema do agronegócio. Essa política de incentivos tem dado resultados significativos. De fato, entre 2004 e 2009, Moçambique concedeu a investidores estrangeiros o direito de explorar mais de um milhão de hectares. (CLEMENTS, 2014, p. 1)

Ao tratar de maneira mais detalhada o caso de Moçambique, verifica-se que o país, antes da abertura ao investimento estrangeiro, detinha por volta de 36 milhóes de hectares de terras cultiváveis, sendo que $16 \%$ disso encontrava-se em cultivo por pequenos agricultores e camponeses. Ademais, dessas terras cultivadas, só 3\% correspondiam propriamente ao setor do agronegócio. Pode-se assim afirmar que o agronegócio era responsável pela exploração de menos de 200 mil hectares em Moçambique. Logo, o agronegócio, apesar de sua projeção globalizante, não estava presente naquele Estado africano. Justamente por conta da ausência do modelo do agronegócio em Moçambique, não surpreende o fato de que $80 \%$ da populaçáo moçambicana esteja vinculada diretamente ao setor agrícola, sendo a maior parte da produçáo destinada ao consumo interno. Isso se deve ao fato do modelo da agricultura familiar ser ainda o principal modelo agrícola em Moçambique. Desta forma, a exploração é feita em pequenas propriedade, em contraposição àquilo em que se baseia o agronegócio: o latifúndio. Sem agronegócio, não há êxodo rural. Sem êxodo rural, não há latifúndio. De fato, dados oficiais retratam que os camponeses de Moçambique estão em sítios cuja área, em média, é de 1,3 hectares. (CLEMENTS, 2014, p. 10)

Em face dos dados mencionados acima, imperativa se torna a confrontação da realidade moçambicana com o discurso das organizaçôes internacionais. Um país que possui entre 15 e 20 milhôes de camponeses não pode ser considerado um território de terra abundante, aberto ao uso intensivo, a não ser que se desqualifique a agricultura praticada por esses camponeses. Eis a consequência ideológica da globalização do agronegócio, que foi mencionada no primeiro parágrafo deste artigo. Qualquer modelo de produção agrícola que não coincida com o método agroindustrial é desconsiderado como alternativa viável. Modelos alternativos de produção agrícola tornam-se invisíveis aos olhos do sistema dominante. 
O discurso, cuja origem encontra-se nos Estados desenvolvidos do Norte, segundo o qual a África é um continente vazio, subutilizado, desperdiçado, é causa de uma corrida por parte das companhias agroindustriais, representadas por seus Estados de origem, que desejam impor o sistema do agronegócio aos Estados africanos em detrimento do sistema tradicional vigente e real. As avaliaçóes, que concluem ser a Savana uma imensa área a ser explorada, não levam em consideração o fato de que a terra ali é muitas vezes utilizada por camponeses conforme outros modelos agrícolas, o que náo significa que aquele espaço esteja livre, disponível ou obsoleto. Vê-se, desta forma, na doutrina sobre o processo de implementação do agronegócio na África, a menção frequente a um processo de grilagem de terras naquele continente, causada pela sujeição da agricultura local à agricultura global com o apoio formal e expresso dos governos locais. (SCOONES; CABRAL; TUGENDHAT, 2013, pp. 4-5)

\section{O Agronegócio Compromete-se Exclusivamente com o Lucro}

A crise global de alimentos, iniciada em concomitância com a crise econômica internacional de 2008, cuja origem pode ser encontrada nas deficiências das colheitas em áreas tradicionalmente de alta produtividade agrícola, no pico do preço do petróleo elevando os custos de produção, no aumento da demanda internacional de alimentos em virtude do crescimento da demanda dos países pobres, nos investimentos de caráter especulativo em culturas de commodities e nas mudanças climáticas, representou um impulso para inserir a segurança alimentar como objetivo primordial das políticas externas de diversos Estados, que dependem da importação de alimentos, como ocorre, por exemplo, com o Japão. (OKADA, 2014, p. 20)

Mas até os Estados autossuficientes na produção de alimentos têm adotado medidas para enfrentar a crise global. Neste grupo encontra-se o Brasil, que passou a se envolver diretamente com projetos de desenvolvimento agrícola em outros territórios. A ideia de levar o agronegócio a Moçambique surge primeiramente em um contexto de crise global alimentar. Porém, outros aspectos surgem de modo a colocar em questão a existência exclusiva deste objetivo primordial. Destaca-se aqui o lançamento pelo governo moçambicano de sua Política e Estratégia Nacional de Biocombustíveis (PEB), com a publicação da Resoluçáo 22, de 21 de maio de 2009, em sintonia com a assinatura por Brasil, Japão e Moçambique do Acordo Triangular para o Desenvolvimento da Agricultura nas Savanas Tropicais de Moçambique, ocorrida menos de quatro meses depois, em 17 de setembro de 2009. (CLEMENTS, 2014, pp. 11-12; CLEMENTS; FERNANDES, 2012, p. 15; CLASSEN, 2013, p. 2)

Percebe-se desde já que o agronegócio não se encontra necessariamente ligado à questão da segurança alimentar. Ao contrário, boa parcela do setor dedica-se à produção 
de matéria-prima a ser utilizada pelo setor energético, como é o caso dos biocombustíveis. A formalização da PEB e assinatura do Acordo Triangular, ambos atos praticados por Moçambique, demonstra que, desde a origem, a inserção do agronegócio naquele país foi orientada para o setor energético.

Já na introdução da referida Resolução 22/2009 do Conselho de Ministros de Moçambique, está expresso que duas consideraçôes motivaram o governo a instituir a PEB, quais sejam, a promoção e o aproveitamento dos recursos agroenergéticos para a segurança energética e a necessidade de fazer face à instabilidade dos preços internacionais dos combustíveis. Em especial, para a produção de etanol, foram identificados quatro culturas capazes de se transformarem em matéria-prima para os biocombustíveis: cana-de-açúcar, mapira doce, mandioca, milho. Para o biodiesel, outras cinco culturas, quais sejam, Jatropha curcas $^{1}$, coco, girassol, soja e amendoim.

\section{Desenvolvimento Agroindustrial da Savana de Moçambique}

Diante da formalização do PEB e face à conjuntura internacional de crise energético-alimentar, a África passa a ser vista como o locus de redenção global. Nesta conjuntura de crise, Brasil, Japão e Moçambique firmam em 2009 o acordo internacional de cooperação triangular, fundado na execução de projetos técnicos capazes de contribuir para o desenvolvimento agrícola do país africano. Representaram o Brasil neste acordo a Agência Brasileira de Cooperação (ABC) e a Empresa Brasileira de Pesquisa Agropecuária (Embrapa). O conjunto desses projetos técnicos recebeu o nome de Programa de Cooperação Tripartida para o Desenvolvimento Agrícola da Savana Tropical em Moçambique (Prosavana). Trata-se da grande iniciativa de cooperação desde o lançamento do Programa de Parceria Japão-Brasil (PPJB), em 2000. (SCHLESINGER, 2013, p. 17)

No que diz respeito ao Prosavana, deve-se ter sempre em mente o fato de que, apesar do acordo ser trilateral, ele decorre de um envolvimento por parte de Moçambique em uma estrutura de cooperação previamente estabelecida entre Japão e Brasil, cuja origem encontra-se no início dos anos de 1970, quando, simultaneamente, fundou-se a Embrapa e instituiu-se o Programa de Cooperação Nipo-Brasileiro para o Desenvolvimento Agrícola dos Cerrados (Prodecer). Tanto a Embrapa quanto o Proceder tornaram-se, nos anos seguintes, exemplos de sucesso do desenvolvimento agrícola compatível com o modelo do agronegócio, em "terra desabitada e estéril” (CLASSEN, 2013, p. 6), apesar das divergências que só puderam ser ouvidas com o fim da Ditadura brasileira.

Na segunda metade dos anos de 1980, de volta ao regime democrático, o Brasil estabeleceu com o Japão o Programa de Treinamento para Terceiros Países (TCTP, na sigla

1 Jatropha curcas é uma planta, cujas sementes contêm cerca de 35\% de óleos vegetais, e muito utilizada para a produção de biodiesel mercadologicamente valorizado. 
inglesa), cujo objetivo era o trabalho em conjunto para a realização de cursos técnicos em países da América Latina e África. Segundo este sistema, Brasil e Japão ofereceriam a outros Estados modelos de cooperação previamente definidos com o intuito de contribuir para o desenvolvimento local por meio da utilização de conhecimentos e tecnologias nipo -brasileiros. (PINO, 2013, pp. 36-37) Pode-se dizer então que a fórmula dos mecanismos trilaterais de cooperação internacional significa a adoção por um Estado terceiro à oferta apresentada bilateralmente por Brasil e Japão, embora não se possa afirmar que se trata de estratégia exclusiva desses países.

O Prosavana é assim o resultado do envolvimento direto de Moçambique em programas de parceria desenvolvidos bilateralmente por Japão e Brasil desde os anos de 1970 e exportados com o fim da Ditadura no Brasil. De fato, em 1985, Brasil e Japão formalizaram um programa de cooperação trilateral na área de desenvolvimento humano com países asiáticos e africanos. (OKADA, 2014, p. 21)

Nos termos do memorando de entendimento firmado em 2009 por Brasil, Japão e Moçambique, o Prosavana foi constituído com o objetivo de melhorar a competitividade do setor agrícola moçambicano para garantir, ao menos em tese, a segurança alimentar, o aumento da produtividade dos pequenos produtores e, especialmente, a realização do excedente em vista da exportação para o mercado japonês. (EKMAN; MACAMO, 2014, p. 7)

O Prosavana, desde sua formulação e instituição, caracterizou-se por ser um programa de investimento estrangeiro no setor agrícola moçambicano com o intuito de adaptá-lo às diretrizes do agronegócio. Por existir uma pretensa identidade natural entre os ecossistemas da Savana e do Cerrado, o tão propalado sucesso do Prodecer no Brasil é apresentado como o fundamento discursivo da necessidade e das vantagens da implementação do Prosavana em Moçambique. De fato, ainda em maio de 2009, antes da assinatura do acordo trilateral, o Brasil recebeu uma missão do MINAG para mostrar in locu o que a parceria nipo-brasileiro pôde fazer, em termos do agronegócio, em seu Cerrado. A proposta ao governo moçambicano era simplesmente repetir a mesma experiência em território africano, o que passou a ser bem-visto imediatamente por Moçambique. Dois meses depois, em julho, durante a Cúpula do G8² em Áquila (Itália), o presidente brasileiro, Luiz Inácio Lula da Silva, e o primeiro-ministro japonês, Taro Aso, formalizaram uma parceria bilateral para o desenvolvimento agrícola da Savana, tendo por modelo o conhecimento adquirido durante a implementação do Prodecer. (FINGERMANN, 2014, p. 134).

O sucesso do desenvolvimento do agronegócio no Cerrado é a história da adoção de um modelo em uma terra desabitada e estéril, sem qualquer discussão acerca das repercussóes

2 G8 é o nome que se dá ao grupo formado pelos sete países mais economicamente desenvolvidos do mundo (Alemanha, Canadá, Estados Unidos, França, Grã-Bretanha, Itália e Japão) mais a Rússia. 
sociais e ambientais. A repressão à liberdade de expressão durante a Ditadura propiciou o conjuntura ideal para a consolidação da terra para a agricultura em larga escala, em detrimento dos elementos e interesses locais. (OKADA, 2014, p. 17) Percebe-se naquele momento, no Brasil, a ocorrência do fenômeno de imposição do sistema agroindustrial sem a mínima ponderaçáo, por parte do governo brasileiro ou japonês, acerca dos impactos socioambientais naquele espaço físico. A invisibilização dos camponeses e, consequentemente, de seu modo de vida, seu modelo de produção e de seus interesses, fez com que o Prodecer fosse implementado segundo diretrizes exclusivamente governamentais, sem qualquer consulta à população local ou a outros sujeitos interessados, característica que tem sido percebida atualmente em Moçambique, conforme reiteradas denúncias da União Nacional de Camponeses de Moçambique (UNAC). (CLASSEN, 2013, p. 28)

Os governos africanos, não apenas em Moçambique, tornaram a promoção do crescimento do agronegócio em seu próprio território um objetivo primordial da política nacional, recebendo para tanto o importante apoio da elite local. A fim de facilitar a adaptação dos interesses estrangeiros na África, os governos dos diversos Estados, com o apoio fundamental de setores privilegiados da sociedade local, têm aderido paulatinamente à política neoliberal, fundada na liberalização da economia com pouca ou nenhuma intervenção estatal, a fim de se garantir a concorrência perfeita aos agentes globalizados. O intuito é implementar nacionalmente a conjuntura político-jurídica ideal para os interesses dos investidores estrangeiros. Esta implementação pode ser identificada com a liberalização da economia local, em especial de seu setor agrícola.

\section{Envolvimento Dos Membros do BRICS em Cooperação na África}

Esta liberalização fincou portanto a base necessária para o investimento dos membros do BRICS 3 , em especial da China e do Brasil, em países africanos, com destaque para Gana e Moçambique, por intermédio dos respectivos programas de cooperaçáo internacional. A doutrina é majoritária ao constatar que a implementação de projetos do agronegócio em território africano, através dos instrumentos internacionais de cooperação agrícola, implicou em vantagens recíprocas. De um lado, as elites locais beneficiaram-se do aporte financeiro enquanto as empresas agroindustriais encontravam a conjuntura político-jurídica favorável à realização de suas atividades; de outro lado, os Estados do BRICS consolidavam-se como importantes players internacionais. (SCOONES; CABRAL; TUGENDHAT, 2013, p. 13)

Além do desenvolvimento agrícola nacional, Moçambique tem dado ênfase à modernização tecnológica como condição imprescindível para seu desenvolvimento econômico

3 BRICS é o nome que se dá ao grupo formado por Brasil, Rússia, Índia, China e África do Sul. 
sustentável. Daí advém a importância de existir, dentro dos programas de cooperação internacional como o Prosavana, um mecanismo de transferência de tecnologia específica ao objeto do acordo. Mas isso não basta, uma vez que há ali carência de investimentos em setores não propriamente agrícolas, mas que de alguma forma lhe são conexos. É este o caso dos investimentos em infraestrutura viária e de comunicação capazes de permitir a simplificação da cadeia produtiva. Os grandes desafios históricos dos países africanos fazem deles locais de baixa capacidade de pesquisa científica e de fragilidade estrutural. Em virtude disso, as ofertas de apoio de países como o Brasil e a China são sempre aceitas sem muitos questionamentos. Há uma desproporção entre as potencialidades de negociação, o que acaba por inviabilizar qualquer modificação do projeto por parte dos Estados africanos. A necessidade de recursos anula qualquer especulação que ultrapasse os limites do debate econômico. O financiamento de projetos de desenvolvimento é, desta forma, bem mais importante do que qualquer cogitação acerca de questóes socioambientais.

Em Moçambique, a criação do Plano Estratégico para o Desenvolvimento do Setor Agrário (PEDSA) representou definitivamente a adoção de um modelo agrícola nacional fundado no agronegócio e nas parcerias público-privadas, cuja justificativa, em consonância com o ideário neoliberal, relacionava-se com a redução de custos de produção e melhoria da eficiência da cadeia produtiva. Há inclusive uma coincidência metodológica entre o PEDSA e o Prosavana, que tem sido vista como indicativo da aceitação soberana do modelo de desenvolvimento agrícola por Moçambique, qual seja, o fomento de um setor agrícola orientado para o mercado externo, capaz de transformar a economia fundada no trabalho camponês em uma economia considerada ideologicamente moderna. Para tanto, o acesso ao capital externo e à tecnologia agrícola são condiçóes fundamentais. (CHICHAVA et al., 2013, pp. 6-7)

A implementação do Prosavana em Moçambique deve ser examinada enquanto um instrumento de realização de objetivos de política internacional do Brasil e do Japão. No que concerne aos objetivos de política externa do Brasil, o Prosavana pode ser visto como um instrumento agrícola, oferecido a Moçambique, que representa a principal iniciativa de inserção de empresas públicas e privadas brasileiras no continente africano. Para o governo brasileiro, o estabelecimento de programas de cooperação na África significaria portanto um engajamento maior do Brasil em questóes internacionais, o que poderia tornar-se um trunfo importante quando das negociaçóes relativas à reforma das Naçóes Unidas, à criação do BRICS e à influência junto ao G204. (CLASSEN, 2013, p. 3)

4 G20 é o nome que se dá ao grupo formado pelos ministros das finanças e chefes dos bancos centrais das 19 grandes economias mundiais (África do Sul, Alemanha, Arábia Saudita, Argentina, Austrália, Brasil, Canadá, China, Coreia do Sul, Estados Unidos, França, Grã-Bretanha, Índia, Indonésia, Itália, Japão, México, Rússia, Turquia) e da Uniāo Europeia. 
Dentre os vários âmbitos de discussão internacional, o BRICS tem se destacado por sua cada vez mais incisiva articulação com países africanos, especialmente no que se refere à política agrícola, energética e de mineração. De fato, os membros do BRICS, especialmente Brasil, China e Índia, têm sido vistos, na África, não apenas como investidores de recursos financeiros e tecnologia, mas como exemplos de Estados em desenvolvimento que mais têm se aproximado do mundo desenvolvido. Eles são modelos de sucesso para os demais Estados do Sul. Por isso, o discurso desses países, fundado na valorizaçáo do modelo do agronegócio e os consequentes projetos de cooperação, tem sido normalmente aceito e adotado sem ressalvas pelos Estados africanos. (SCOONES; CABRAL; TUGENDHAT, 2013, p. 2)

Tal adesão tem sua razão de ser inclusive quando se examinam os benefícios econômicos que os Estados africanos têm percebido após a implementação das parcerias com os membros do BRICS. Toma-se o caso de Moçambique como exemplo. Desde que se iniciaram os programas de cooperação agrícola com o Brasil e a China, houve um aumento significativo dos níveis de investimento privado e um relativo melhoramento tecnológico naquele país. (CHICHAVA et al., 2013, p. 7) Para um Estado habituado à carência financeira, à inexistência de alternativas tecnológicas e às assimetrias dos acordos Norte-Sul, a entrada em cena de China e Brasil, com seu vigor econômico e tecnológico, devolveu a Moçambique a perspectiva de um desenvolvimento consistente. Isso não é pouca coisa. Se se analisarem os índices da atividade comercial existente entre Brasil e os países africanos, houve um aumento de 600\% entre 2002 e 2011. (SCHLESINGER, 2014, p. 4)

\section{Benefícios Econômicos Não se Traduzem em Benefício Sociais}

Uma questão que se póe de forma incisiva na doutrina é em que medida a população desses países africanos tem se beneficiado desse aumento da atividade comercial internacional. Sabe-se das dificuldades de transformar as conquistas macroeconômicas em melhorias na qualidade de vida dos integrantes de uma determinada sociedade. O Brasil mesmo passou e, em certa medida, ainda passa pelo paradoxo de ser uma das economias mais vigorosas do mundo e, simultaneamente, possuir uma massa populacional alijada do exercício de direitos socioeconômicos fundamentais. É neste âmbito que se encontram as críticas mais ácidas aos processos de cooperação internacional na África.

Isso tem se refletido nos relatórios do Fundo Monetário Internacional (FMI) e do Banco Mundial sobre a situação de Moçambique. Essas instituições internacionais declaram-se otimistas quanto ao futuro do país, apesar das evidentes fragilidades de sua política institucional, aliadas ao caráter antidemocrático do sistema político nacional. Independente das dificuldades e fragilidades políticas, a economia Moçambique tem sido retratada na doutrina como exemplo de sucesso regional, ao ter completado duas décadas de crescimento contínuo. (FINGERMANN, 2014, p. 91) 
Contudo, os avanços econômicos não impedem que se constate a ocorrência de um fenômeno típico dos países em desenvolvimento, qual seja, o enriquecimento acelerado da elite local e o empobrecimento das demais classes sociais, o que explica a concentração da renda nacional. Não é difícil deduzir a existência de tal fenômeno em Moçambique, levando-se em conta a persistência de dois fatores: a fragilidade democrática e o crescimento econômico. Durante a Ditadura brasileira (1964-1988), quando ocorreu o conhecido Milagre Econômico, esse fenômeno foi percebido no Brasil. Um regime autoritário e antidemocrático, em uma conjuntura econômica de crescimento vigoroso, deu origem ao discurso oficial de que o bolo - as riquezas nacionais - deveria crescer antes de ser partilhado. O povo deveria ter paciência e aguardar o momento ideal para a repartição das riquezas nacionais. $\mathrm{O}$ bolo cresceu e sua divisão continua a ser um objetivo. A perversa concentração de renda no Brasil é resultado disso. Por que em Moçambique seria diferente?

Reforça esta percepção a posição da UNAC de alerta sobre o perigo do Prosavana criar uma explosão de camponeses sem-terra no país, incentivando o êxodo rural, aumentando a crise urbana, causando o empobrecimento das comunidades rurais, tornando os pequenos agricultores dependentes de investimentos estrangeiros em larga escala, prejudicando o meio ambiente e comprometendo a sustentabilidade socioambiental. Essas críticas chegam inclusive a identificar o Prosavana como uma espécie de Cavalo de Troia brasileiro. (CHICHAVA et al., 2013, p. 15)

Em termos estritamente econômicos, entretanto, o resultado das iniciativas internacionais em Moçambique tem entusiasmado seu governo. Por isso mesmo, o Brasil tem sido consultado acerca da possibilidade de ampliaçáo da cooperação bilateral em outros domínios, não exclusivamente econômicos. (LIMA, J. D. F., 2012, p. 28)

\section{Brasil na África: Protagonismo Internacional e Fortalecimento da Indús- tria Nacional}

Diferentemente do Japão, que depende da importação de alimentos para atender a 60\% da demanda interna (OKADA, 2014, p. 1), o Brasil não necessita de comprar a produção agrícola de Moçambique, seja para fins alimentares, seja com objetivos energéticos. Neste último aspecto, o caso brasileiro se distingue também da situaçáo existente na China e na Índia. Logo, diante desses três países membros do BRICS diretamente interessados em firmar parcerias internacionais na África, o Brasil é o que menos depende dos resultados concretos desses acordos. $\mathrm{O}$ interesse do Brasil configura-se essencialmente no alargamento das margens de influência geopolítica e sua consolidação como importante ator na cena internacional. (SCHLESINGER, 2014, p. 4)

Mas não apenas os interesses brasileiros enquanto sujeito de Direito Internacional impulsionam o Estado a estabelecer acordos de cooperação econômica com países africanos, 
em especial com Moçambique. É óbvio que o Brasil procurar aumentar seu espaço e peso nos debates multilaterais. Porém, além disso, há nesses mecanismos internacionais a demonstração do caráter estratégico dado à expansão das empresas brasileiras ${ }^{5}$ - públicas e privadas - rumo a outros territórios nacionais. Além dos projetos agrícolas, há outros de natureza diversa, destacando-se aqueles relativos à exploração de petróleo e minérios, assim como iniciativas de intervenção em infraestrutura. (SCHLESINGER, 2013, p. 9) Por esta razão, diz-se que o engajamento do Brasil na África deve ser compreendido sob duas perspectivas. A primeira caracteriza-se por ser uma alternativa exclusivamente governamental. Ao ter em vista uma projeção internacional, o Brasil une-se a tradicionais potências econômicas do Norte $^{6}$, no caso o Japão, para atender a necessidades exclusivas de seu parceiro do mundo desenvolvido. A segunda perspectiva traduz-se na abertura de fronteiras de exploração para os diversos setores econômicos nacionais, garantindo-lhes matéria-prima, mercado e demanda de negócios rentáveis. (CABRAL; SHANKLAND, 2013, p. 17)

O fato do Brasil possuir um passado colonial de mais de três séculos e ser ainda um Estado em desenvolvimento do Sul facilita a disposição dos Estados africanos em abrir seu território às iniciativas de um país sem qualquer passivo colonial. Ademais, os laços culturais e raciais ${ }^{7}$ também facilitam a aproximação do Brasil com o continente africano. (AVELHAN, 2013, p. 41) A entrada de investidores brasileiros na África não tem sido nada traumática. Pode-se fazer tal afirmação, pelo menos, no que concerne à fase de negociaçóes internacionais. A implantação dos projetos, por sua vez, tem se mostrado muito mais conflituoso. O Brasil é visto como um parceiro da África e sua liderança internacional é até mesmo desejada pelos africanos.

Por não ser estruturalmente dependente da produção agrícola africana, o Brasil encontra-se ainda atrás da China e da Índia quando se analisam os montantes financeiros aportados nos Estados africanos. Além disso, o modelo de ajuda brasileiro caracteriza-se por se orientador pelo princípio da não interferência, (EKMAN; MACAMO, 2014, p. 1) isto é, tem-se como condição fundamental para as relações internacionais na África o respeito à soberania alheia, o que torna mais gradual a realização dos processos de cooperação internacional. Só se formalizam instrumentos jurídicos na medida em que todas as partes possam livremente expressar seu consentimento prévio, o que demanda normalmente mais tempo do que em situaçóes de diplomacia incisiva.

5 Estão presentes na África diversas empresas e instituiçôes públicas e privadas do Brasil. Dentre elas, destacam-se BNDES, Embrapa, Petrobrás, Senai, Senac, Fiocruz, diversas universidades, JBS, Marfrig, Brasil Foods, Oderbrecht, Camargo Correa, Gerdau, CSN, Coteminas, Vale, Fibria, Ambev, Artecola, Tigre, Embraer e Marcopolo. (AVELHAN, 2013, p. 31)

6 Na África, o Brasil também possui projetos de cooperação trilateral com outros Estados desenvolvidos como, por exemplo, os Estados Unidos. (ABREU, 2013, p. 14)

7 O Brasil é o país com a maior população negra existente fora do continente africano. 
Percebe-se assim que, apesar das diferenças estratégicas fundadas em distintos objetivos imediatos - o que pode ser percebido pela análise dos discursos oficiais de ambos os governos -, Brasil e China, no que concerne aos programas de cooperação agrícola na África, aproveitam-se de uma narrativa de fundo histórico para facilitar a aproximação junto aos Estados africanos. Enquanto o Brasil apresenta-se como um parceiro preocupado em saldar a dívida da escravidão negra, a China roga a si o tradicional papel de opositora às corridas colonialistas de outrora.

\section{Rivalidades Japonesas na Agricultura: China e Estados Unidos}

Por ser o Prosavana a principal iniciativa do Brasil na África e visto ser este programa o resultado da longa parceria existente entre Brasil e Japão, há quem afirme ser a corrida contemporânea por terras na África, que envolve diretamente Brasil e China, na verdade, um dos traços mais contemporâneos da tradicional rivalidade entre Japão e China. $\mathrm{O}$ Brasil seria, neste caso, tão somente um representante dos interesses japoneses naquele continente. Nesse contexto de competição internacional, o programa nipo-brasileiro de investimento no setor agrícola de Moçambique tornar-se-ia importante instrumento no equilíbrio de forças no extremo-oriente. Com efeito, a China é um dos atores mais ativos na cena internacional econômica, especialmente na África, com quem tem estabelecido parcerias desde os anos de 1980, o que tem preocupado substancialmente o governo japonês. (CLASSEN, 2013, p. 18)

A presença da China em Moçambique é, junto com a necessidade de importação de alimentos para o mercado interno, um dos principais fatores que incentivam o Japão a se envolver no Prosavana, em associação com o Brasil. A China é vista pelo governo japonês como o principal rival para os investimentos agrícolas offshore, ao ponto de sua atividade na África ser considerada um obstáculo concreto à expansão dos interesses empresariais japoneses naquela região. (OKADA, 2014, p. 23)

As preocupaçóes japoneses se justificam na medida em que a China é a detentora do mais amplo e sedimentado sistema de cooperaçáo para o desenvolvimento de Estados do Sul. Dentro da organização estatal chinesa, cabe ao Departamento de Ajuda a Países Estrangeiros, submetido ao Ministério do Comércio, a atribuição de implementar tais programas de cooperação econômica internacional, dedicados especialmente à infraestrutura, agricultura, mineração e energia. Ademais, esses programas chineses têm se destacado globalmente, pois são realizados em consonância com os princípios da cooperação, da igualdade e do ganho recíproco. Isso faz com que a China seja vista com bons olhos pelos Estados em desenvolvimento e torne-se um parceiro preferencial. Contudo, a admiração geral pelo sistema de cooperação internacional chinesa não impede a existência de muitas críticas, notadamente no que concerne à transferência de mão de obra chinesa para os países onde os programas são implementados. (AVELHAN, 2013, p. 25) 
No contexto da concorrência internacional, não apenas a China é motivo de preocupação por parte do Japão. Também os Estados Unidos são considerados outro rival na questão agrícola, notadamente no que concerne à produção de soja. Como já foi mencionado acima, o Japão é grande dependente da importação de produtos agrícolas, dentre os quais destaca-se a soja. Até meados dos anos de 1970, os Estados Unidos eram o único grande produtor mundial de soja.

A importância estadunidense na produção de soja é decorrência de uma mudança na forma de enxergar as potencialidades naturais dessa leguminosa. Em 1904, cientistas do Instituto Tuskegee, localizado no Alabama, identificaram grandes quantidades de óleo e proteína na soja, vislumbrando consequentemente a possibilidade de utilizá-la na produção de ração animal e óleo vegetal. Alguns anos depois, em 1920, surgia a American Soybean Association (ASA), que inseriu definitivamente a soja na agenda governamental daquele país. Nos anos de 1930, a soja era encontrada em mais de um milhão de hectares do território dos Estados Unidos. (FERNÁNDEZ, 2007, pp. 16-17) Mais recentemente, em meados dos anos 2000, a produção anual de soja daquele país alcançava o patamar de 80 milhões de toneladas, (FERNÁNDEZ, 2007, p. 102) enquanto a safra 2014/2015 de sua produção ultrapassou a casa das 108 milhóes de toneladas. (TORRES, 2015)

A hegemonia dos Estados Unidos neste setor agrícola motivou o Japão, que é um Estado com sérias limitações territoriais, a fomentar a produção da soja em outras regióes, com o propósito de induzir o surgimento de alternativas ao monopólio estadunidense. É neste contexto que são firmados os primeiros acordos de cooperaçáo com o Brasil, que darão origem, na década de 1970, ao Prodecer. Como resultado de longo prazo, a parceria nipo-brasileira no setor agrícola será um dos motivos pelos quais o Brasil se tornará, em 2006, o primeiro lugar dentre os países exportadores de soja, atingindo a marca de 39,62 milhôes de toneladas enviadas ao exterior. (FERNÁNDEZ, 2007, p. 103)

Apesar de não ser o maior produtor de soja, posição esta ocupada pelos Estados Unidos, o Brasil é seu maior exportador. Não há qualquer contradição neste fato. Isso mostra simplesmente que, enquanto nos Estados Unidos a produção é destinada ao mercado interno, o Brasil se caracteriza por ser um país que tem em vista utilizar os resultados de sua agroindústria como bens de exportação. A proposta do Prosavana é fazer de Moçambique um novo Brasil, isto é, aproveitar a conjuntura política não-democrática para inserir o agronegócio como modelo industrial em larga escala de viés exportador.

A decisão japonesa de participar da cooperação trilateral em Moçambique pode ser compreendida, desta forma, como uma tentativa de minimizar ainda mais a tradicional hegemonia dos Estados Unidos na produção de soja, apesar dos avanços significativos da produção de soja brasileira. De maneira mais específica, o Japão pretende diversificar as regióes de abastecimento global de soja. Percebe-se, portanto, que não mais interessa ao governo japonês manter o mercado internacional concentrado nas mãos de apenas dois 
países: Brasil e Estados Unidos. Aquele foi importante nas últimas décadas para quebrar o monopólio deste, mas isso não significa que a bipolarização da produção de soja seja mantida por muito tempo. É também neste contexto de pulverização do fornecimento de soja que se encontra a importância atual de Moçambique para o Japão. Conclui-se assim que o Prosavana pretende, no mínimo, instituir uma tripolarização do fornecimento global de soja. (OKADA, 2014, p. 30)

Para maximizar suas chances de penetração em território africano, o Japão tem se aproveitado dos novos esquemas de parceria de tipo Sul-Sul implementados pelo Brasil com outros Estados em desenvolvimento, em especial com aqueles de língua portuguesa. A expectativa do Japão quanto ao sucesso do Prosavana é suficiente para que a JICA considere a possibilidade de expandir o modelo trilateral de cooperação agrícola, fundado em sua participação conjunta com o Brasil e outro Estado africano. Fala-se inclusive em repetir brevemente a experiência de Moçambique em Angola. (OKADA, 2014, p. 23)

\section{Cooperação Internacional Sul-Sul: Características Comuns}

A cooperação Sul-Sul é como se designa uma espécie de acordo internacional, que tem em vista o desenvolvimento comum, adotada pelos Estados em desenvolvimento ou Estados do Sul. Existem portanto dois aspectos formais essenciais para a identificação da cooperação Sul-Sul: um subjetivo, relativo às partes envolvidas no acordo internacional, e outro objetivo, concernente à matéria do acordo.

Em princípio, qualquer vínculo jurídico, estabelecido entre Estados considerados subdesenvolvidos, que tenha por objeto a implementação de mecanismos de desenvolvimento socioeconômico, pode ser designado como um caso de cooperação internacional Sul-Sul. Basta apenas que estejam envolvidos Estados do Sul e que o objeto seja a cooperação internacional para o respectivo desenvolvimento nacional. Diante disso, forçosa é a constatação de que, a princípio, os acordos de cooperação firmados pelo Brasil com os países africanos, em especial Moçambique, assumem este formato.

O princípio que sustenta os mecanismo de cooperação Sul-Sul é o de que os Estados em desenvolvimento não dependem mais - ou melhor, nunca dependeram - dos congêneres desenvolvidos para conseguir deixar para trás o subdesenvolvimento. Ao contrário, é plenamente possível - e bem mais eficiente - conquistar benefícios individuais através de sistemas de cooperaçáo que prevejam de forma estrita a reciprocidade. Quando todas as partes envolvidas têm, a grosso modo, os mesmos objetivos, a conjugação de interesses individuais facilita a realização dos propósitos coletivos. Trata-se da conjugação de forças daqueles que se encontram no mesmo patamar de desenvolvimento. Além disso, o fato de não haver grandes desigualdades entre as partes do acordo de cooperação Sul-Sul faz com que suas demandas sejam relativamente uniformes, o que minimizaria substancialmente as possibilidades da ocorrência de situaçóes de tipo neocolonial. 
A cooperação internacional Sul-Sul busca, portanto, introduzir uma nova ótica do que seja o desenvolvimento socioeconômico dos Estados do Sul, de modo a valorizar o acordo entre países que estão em busca do pleno desenvolvimento ou, pelo menos, do grau de desenvolvimento já alcançado pelos Estados do Norte. Por ser uma alternativa a esquemas de interaçáo internacional que se confundem com o neocolonialismo, essa espécie de cooperação internacional, realizada entre si pelos Estados em desenvolvimento, funda-se evidentemente nos princípios da soberania permanente sobre os recursos naturais, da cooperação, da não-intervenção e da horizontalidade de interação. Tal arcabouço jurídico internacional teria, desta forma, a possibilidade de realizar uma inserção diferenciada dos Estados do Sul na comunidade internacional, repercutindo favoravelmente em suas relaçóes com os próprios Estados do Norte. (AVELHAN, 2013, pp. 18-19)

A cooperação Sul-Sul passa a ser a expressão jurídica da mudança na correlação de forças no sistema internacional, que tem sido a característica das primeiras décadas do séc. XXI. Os Estados em desenvolvimento, fazendo valer sua soberania conquistada a partir dos diversos movimentos nacionais de descolonização dos séculos XIX e XX, pretendem garantir finalmente a realização de sua independência econômica em relação às antigas potências coloniais e imperialistas. Para tanto, os mecanismos de cooperaçáo Sul-Sul têm se apresentado como uma importante alternativa.

Neste contexto, Brasil, China e Índia, que são ainda considerados países em desenvolvimento, não têm perdido a oportunidade de procurar outros Estados do Sul, em vista da celebração de acordos de cooperação econômica, configurando-se na espécie Sul-Sul. O sucesso deste tipo de interação internacional tem feito com que surja objetivamente um novo equilíbrio geopolítico, em que aqueles Estados assumem uma posição de destaque nas discussóes internacionais. (SCHLESINGER, 2013, p. 7)

\section{Cooperação Sul-Sul: A Experiência do Brasil}

Os acordos de cooperação estabelecidos pelo Brasil na África, como ocorre com o Prosavana em Moçambique, têm a pretensão de se constituir em instrumentos internacionais de tipo Sul-Sul, capazes de garantir a repartição justa e equitativa de benefícios mútuos, fundada no princípio da solidariedade.

Da parte dos Estados africanos, tendo como exemplo Moçambique, os acordos de cooperação Sul-Sul são vistos como uma oportunidade de aprendizado, pois, não apenas o Brasil, mas também outros importantes países em desenvolvimento, como a China e a Índia, são considerados exemplos do sucesso de modelos alternativos de desenvolvimento dentro do bloco dos Estados do Sul. No caso específico do Prosavana, Moçambique pretende copiar em seu território o modelo agrícola adotado pelo Brasil a partir dos anos de 1970, considerado, em termos propagandísticos, um formato de grande sucesso. Visto 
ser tal modelo agrícola brasileiro, fundado no agronegócio, a demonstração de que há alternativas realizáveis de desenvolvimento autônomo para os Estados ex-colonizados, o governo moçambicano pretende repeti-lo em seu território por intermédio do Prosavana.

Ao se analisar a posição do Brasil no esquema de cooperação Sul-Sul, verifica-se que seu discurso oficial pauta-se inequivocamente pelo princípio da diplomacia conjunta, baseada na solidariedade. O Brasil apresenta-se como um Estado do Sul capaz de transferir a outros Estados em desenvolvimento seu saber-fazer em termos de desenvolvimento econômico, levando-se em conta a experiência local. A princípio, ao menos formalmente, a ideia em que se funda a proposta de cooperação brasileira para a África refere-se à adaptação do formato brasileiro à conjuntura sociocultural das populaçóes locais, o que implica evidentemente na não-imposição de condições, na não-associação para interesses comerciais, no respeito à soberania alheia e na não-interferência nos assuntos internos de Estados terceiros. Diante disso, a cooperação proposta pelo Brasil aos Estados africanos é considerada distinta das tradicionais formas de cooperação levadas a cabo tradicionalmente pelos Estados do Norte. (CABRAL; SHANKLAND, 2013, p. 5) O caráter horizontal da parceria brasileira é apresentado como contraponto ao sistema vertical existente nas cooperaçôes Norte-Sul. (CHICHAVA et al., 2013, p. 7) É por este mesmo motivo que o Brasil recusa-se, nos esquemas de cooperação na África, a ser chamado de doador, termo que se refere normalmente às cooperaçóes verticalizadas de tipo Norte-Sul. (CABRAL et al., 2013, p. 2)

O Brasil, rechaçando qualquer vinculação com os mecanismos de cooperação vertical, descreve seus programas de parceria na África como exemplos de relaçóes internacionais mutuamente benéficas. Esses benefícios recíprocos não seriam apenas de natureza econômica e diplomática, mas, especialmente, de natureza solidária, em que a aprendizagem e convivências são mútuas. (CABRAL et al., 2013, p. 2)

Simboliza bem o papel dado a este tipo de cooperação pelo Brasil o discurso proferido pelo presidente Lula, em Maputo, em que se confirmou compromisso moral do Brasil com a realização da soberania alimentar de Moçambique.

"A maior demonstração de soberania de um país não é ele ter bomba atômica, não é ele produzir chip, é ele ter capacidade de produzir todo o alimento necessário para o seu povo, e nisso o Brasil tem acúmulo de experiência, assistência técnica e resultado para partilhar com Moçambique”. (MONTEIRO, 2010)

A cooperação praticada pelo Brasil na África segue, portanto, as diretrizes fundamentais da política externa brasileira, que consistem na defesa da paz, no incentivo da adoção universal de mecanismos de solução pacífica de controvérsias, na valorização da igualdade internacional, na garantia da autodeterminaçáo dos povos e na busca permanente 
pelo desenvolvimento. Todos esses fundamentos em consonância com o objetivo de reduzir de forma eficiente e definitiva as desigualdades socioeconômicas existentes entre os Estados do Norte e do Sul.

Mas isso não é tudo. Como pode ser percebido da postura solidária do Brasil em face do desafio da realização da segurança alimentar em Moçambique, os projetos de cooperação internacional Sul-Sul demonstram a vontade do Estado brasileiro em estreitar relaçóes com outros países em desenvolvimento em vista da realização de uma integração política, econômica, social e cultural independente dos interesses dos Estados desenvolvidos.

\section{Cooperação Internacional Sul-Sul: Ação sob Demanda}

Além dos princípios da soberania, cooperação, solidariedade, não-intervenção, não-imposição de condições, reconhecimento da experiência local, a cooperação de tipo Sul-Sul proposta pelo Brasil funda-se na ação sob demanda, isto é, o Brasil só age internacionalmente quando provocado de forma livre e soberana pelo governo de outro Estado.

A noção de ação sob demanda inscreve-se de maneira ampla dentro do espectro da normatividade própria e decorrente do princípio da soberania dos Estados. Porém, é possível examiná-la de uma forma mais estrita, de acordo com a política de cooperação técnica entre países em desenvolvimento. No caso brasileiro, após a instituição da $\mathrm{ABC}$, as iniciativas de cooperação Sul-Sul passaram a se pautar por uma diferenciação substancial daquilo que sempre existiu enquanto cooperaçáo tradicional, confundida com a cooperação internacional Norte-Sul ou vertical. Com o modelo de cooperação Sul-Sul, rejeitouse sumariamente qualquer traço de assimetria e desigualdade entre as partes envolvidas, independentemente de suas atribuições individuais, isto é, não mais se distinguem as partes de um acordo nas figuras de prestadoras ou receptoras. Esta distinção ou hierarquia entre os sujeitos de um acordo internacional de cooperação seria a prova cabal de que as propostas de cooperação tradicional sempre detiveram em seu cerne a vocação para a desigualdade. Logo, concluiu-se que a cooperação Norte-Sul não era efetivamente um exemplo de parceria, no sentido estrito do termo. (AVELHAN, 2013, p. 22) Fundado no princípio da igualdade entre as partes em cooperação, o sistema Sul-Sul exige como condição principal a prévia manifestação soberana por parte do Estado em desenvolvimento que deseja se aliar com outro Estado em desenvolvimento. O Brasil, de acordo com seu discurso oficial, segue este princípio. Eis o que se chama de ação sob demanda em cooperação Sul-Sul: o Estado, no caso o Brasil, deve permanecer inerte até que haja a provocação por parte de um sujeito de Direito Internacional, que faça parte do grupo de países em desenvolvimento, em vista da construçáo de um mecanismo conjunto de desenvolvimento socioeconômico.

Nada pode ser mais atraente para os Estados africanos do que esta proposta de cooperaçáo Sul-Sul, diante da lembrança recente de ser passado colonial. Para quem foi 
obrigado a conviver com a submissão por séculos, para quem teve que lutar pela própria independência, torna-se cativante a constatação prática $a b$ initio da disposição do Estado potencialmente parceiro em respeitar integralmente sua soberania. Isso fica ainda mais patente quando é acompanhada de discursos de valorização da solidariedade e não-interferência. (FINGERMANN, 2014, p. 103)

Em favor do protagonismo brasileiro no sistema internacional de cooperação SulSul, destaca-se o fato de que o Brasil não possui um passado colonialista, nem impóe condiçóes políticas ou econômicas para seu envolvimento em projetos ou programas de desenvolvimento local. Pelo contrário, por ser um parceiro do Sul com seus próprios dilemas nacionais, o Brasil evita de todas as formas interferir nos assuntos domésticos alheios, o que lhe tem garantido a confiança necessária por parte dos governos africanos. (NOGUEIRA; OLLINAHO, 2013, p. 3)

A implementação dos acordos de cooperação Sul-Sul que envolvem o Brasil e os Estados africanos ocorre sob diversas formas, tendo em vista as aspiraçóes recíprocas. Todavia, percebe-se como característica homogênea a participação não apenas do setor público brasileiro, como também das empresas privadas. $\mathrm{O}$ envolvimento do Brasil em projetos decorrentes de acordos de cooperação internacional Sul-Sul se dá sob a forma de assistência técnica, investimento direto ou empréstimos do governo. (SCHLESINGER, 2013, p. 7)

\section{Prosavana: Cooperação (Norte)-Sul-Sul}

Moçambique é o Estado da África subsaariana que mais tem se beneficiado dos programas de cooperação técnica do Brasil. Em 2010, Moçambique recebeu 81\% dos recursos brasileiros destinados àquela região. (FINGERMANN, 2014, p. 83) Ocorre, entretanto, que os projetos brasileiros de cooperação agrícola, dos quais se destaca o Prosavana, não são estabelecidos bilateralmente entre o Brasil e o Estado africano. Ao contrário, como já foi visto anteriormente, esses projetos têm sempre a participação de um Estado do Norte.

No que concerne ao Prosavana, o Japão é o país desenvolvido que se coloca como parte do acordo, junto com Brasil e Moçambique. Pode-se então, desde já, começar a questionar se o Prosavana é realmente um instrumento de cooperaçáo Sul-Sul.

Corrobora com o questionamento do caráter Sul-Sul do Prosavana a posição doutrinária de Natalia Fingermann (2013, p. 1), que afirma ser o programa resultado de um acordo trilateral em Moçambique, que inclui princípios da cooperação Sul-Sul. Percebese, desde já, que o modelo de cooperação trilateral do Prosavana não cumpre plenamente os requisitos do formato de cooperaçáo Sul-Sul, mas apenas adota algumas diretrizes

próprias a tal formato. É neste sentido que se interpreta a conclusão da autora de que o 
acordo trilateral, apesar de ser de um determinado formato, inclui alguns princípios da cooperação Sul-Sul.

A Federação de Órgãos para Assistência Social e Educacional (FASE), organização não-governamental brasileira sem fins lucrativos, dedicada à Justiça Ambiental e à segurança alimentar, tem frequentemente criticado o caráter Sul-Sul do acordo de cooperaçáo que deu origem ao Prosavana. Para a FASE o programa implementado em Moçambique é, na verdade, um projeto bilateral nipo-brasileiro, fundado em um movimento de expansão dos investimentos privados brasileiros, que deveria ser considerado como uma espécie de cooperação internacional Norte-Sul. (CLASSEN, 2013, p. 31)

O primeiro desvio em relação ao formato da cooperação Sul-Sul refere-se ao aspecto subjetivo. Segundo a concepçáo formal dos acordos horizontais de cooperação, devem as partes do acordo internacional ser apenas Estados em desenvolvimento. Tal determinaçáo subjetiva teria o propósito de blindar as partes economicamente mais frágeis de pretensôes e imposiçóes dos Estado do Norte, dissonantes dos desafios comuns aos Estados do Sul.

Entretanto, não se pode negar que haja a realização de projetos e programas que envolvem diretamente os Estados do Sul, apesar do fato de Estados do Norte serem partes do acordo internacional. Veja-se o caso do Prosavana. Apesar de o Japão ser parte do acordo internacional de cooperação, não se questiona o fato de que Moçambique e Brasil são os grandes protagonistas de sua realização. A atuação do Japão neste projeto restringe-se à consecução de seus objetivos de segurança alimentar própria e geopolíticos.

Não há que se negar, tampouco, o fato de que a participação do Japão no Prosavana, mesmo que marginal, compromete substancialmente a realização da cooperação internacional Sul-Sul. Por isso, diante da participação de Estados do Norte em acordos de cooperação instituídos em tese para se constituírem no modelo de tipo Sul-Sul, verificase, na verdade, a ocorrência de uma cooperação internacional de tipo (Norte)-Sul-Sul, em que a atuação e os interesses de países desenvolvidos são inseridos no contexto Sul-Sul de forma sutil e dissimulada. Adota-se o discurso da cooperação solidária entre países em desenvolvimento para tentar legitimar a participação de Estados do Norte, mesmo que de maneira camuflada. Para tanto, necessita-se da conivência de um dos Estados do Sul, que passa a agir como mandatário dos interesses do Estado do Norte. No caso do Prosavana, é o Brasil que figura nesta posição, pois foi quem intermediou a inserção dos interesses japoneses em Moçambique sob o formato da cooperaçáo Sul-Sul.

O descompasso entre o discurso e a prática tem sido identificado como uma postura hipócrita por parte, especialmente, dos Estados provedores, como o Brasil, que se utilizam de um ideário anticolonial para se beneficiar e permitir concomitantemente a entrada em países receptores, como Moçambique, de interesses associados às grandes potências imperialistas, o que é o contrário do que se propóe com a cooperação Sul-Sul. 
Como decorrência dessa incoerência fundamental e como já salientado anteriormente, tem-se utilizado na doutrina o termo Cavalo de Troia para definir os acordos internacionais trilaterais de cooperação Sul-Sul, em que uma das três partes não está em desenvolvimento. Há diversos autores, conforme se depreende do trabalho de Lívia Liria Avelhan (2013, p. 28), que chegam mesmo a identificar o fenômeno como uma espécie de subimperialismo, isto é, o Estado do Sul, mandatário dos interesses do Estado do Norte, agiria em nome próprio para impor em outro Estado do Sul um sistema de exploração de natureza imperialista. Para esses autores, a expansão da presença internacional de potências médias, como Brasil, China e Índia, tende a impor de cima para baixo modelos de exploração econômica a países frágeis, como o são aqueles que se encontram na África, por meio de acordos internacionais de cooperação trilateral e por meio da atuação direta de importantes companhias daquelas potências médias. A presença do Japão no Prosavana é, por exemplo, indicador da existência de um elemento de cooperação antagônica, que tem sido associado ao subimperialismo brasileiro. (AVELHAN, 2013, p. 63) Isso significa que, no caso do Prosavana, o Brasil agiria para simular a existência de um novo modelo de cooperação, fundado no princípio da horizontalidade, mas que, na verdade, seria o tradicional modelo vertical da cooperação Norte-Sul. Entretanto, como há a intermediação dos interesses do Norte e do Sul por uma potência média, adota-se aqui o conceito de cooperação (Norte)-Sul-Sul.

Os desvios desse modelo de cooperação (Norte)-Sul-Sul não traz prejuízos apenas aos Estados do Sul que se encontram em uma das extremidade da operação, como ocorre com Moçambique no Prosavana. Aquele país em desenvolvimento que age enquanto mandatário dos interesses do Norte em território do Sul também náo escapa de ser inserido em um vínculo jurídico verticalizado próprio dos mecanismos de cooperação tradicional Norte-Sul.

De fato, no Prosavana, pesquisadores da Embrapa desconfiam do acordo trilateral de cooperação, pois percebem que a aproximação japonesa tem o propósito de permitir a apropriação indireta por parte daquele país do conhecimento brasileiro sobre culturas tropicais. Em sua tese de doutorado sobre o tema, Fingermann (2014, p. 134) reproduz depoimento do Entrevistado 8, agente da ABC, segundo o qual: "a cooperação Norte-Sul quer se apoiar na nossa expertise, no nosso conhecimento, na facilidade da língua e na tecnologia que nós dominamos".

\section{Prosavana e Ausência de Democracia Efetiva}

Visto que Brasil e Japão são os idealizadores do Prosavana, que posteriormente foi oferecido a Moçambique, que o aceitou como se se tratasse de uma espécie de contrato de adesáo, são eles, por conseguinte, os grandes responsáveis por sua implementaçáo 
em território moçambicano. Por conta disso, não só a elaboração, mas a forma de sua realização caracterizam-no como um projeto top-down (OKADA, 2014, p. 32), isto é, um instrumento concretizado de cima para baixo. Suas decisôes mais importantes são tomadas em reunióes entre os Estados partes sem que haja a menor possibilidade de questionamento de seus pressupostos formais e materiais, que acabam por dar preferência aos interesses individuais de Brasil e Japáo e direcionar o capital privado a setores estratégicos da economia de Moçambique.

A falta de espaço para questionamentos prévios, quando da negociação dos termos do acordo de cooperação trilateral, e para questionamentos posteriores, quando da implementação de tais termos, agrava ainda mais o caráter não democrático do Prosavana e compromete a materialização do requisito da diplomacia brasileira, fundada na açáo sob demanda. Como consequência da falta de participação substancial de Moçambique na formulação e implementação deste programa de cooperação internacional (Norte)-SulSul, seus desdobramentos fáticos não têm levado em consideração os impactos socioambientais, mas tão somente os econômicos.

A lógica capitalista de lucro a qualquer preço, aliada a ausência de participação democrática, isto é, da participação não apenas de Moçambique enquanto sujeito de Direito Internacional, mas especialmente da população moçambicana diretamente afetada, é a razão da ocorrência de grandes danos sociais e ambientais. Tudo isso com a conivência do governo moçambicano apoiado nas elites locais. Seja durante a Ditadura brasileira em que o Prodecer foi implementado, seja agora com o Prosavana, o que se percebe é a repetição da história: obsessão pelo crescimento econômico às custas do equilíbrio ambiental e da paz social.

Não é à toa que o Prosavana é um programa inspirado na experiência de desenvolvimento agrícola do Cerrado brasileiro, fundado na lógica do agronegócio e realizado a partir dos anos de 1970 pelo governo brasileiro antidemocrático, autoritário e ditatorial, apoiado pelas elites locais, em cooperação com o Japão. O Prosavana é o reflexo do Prodecer. Por consequência, o Prosavana tende a repetir os resultados socioambientais do Prodecer. (CHICHAVA et al., 2013, p. 12)

Desde o início de sua implementação, o Prodecer tem significado para o Brasil a exclusão social, o êxodo rural e a concentração de terras, que transformaram em pouco tempo camponeses em trabalhadores sem-terra. O Movimento dos Trabalhadores SemTerra (MST) originou-se das contradiçôes do sistema produtivo próprio ao agronegócio, incentivado pelo governo brasileiro a partir dos anos de 1970.

Ao tratar das contradições do agronegócio, pode-se mencionar, por exemplo, que, em 2010, apesar do aumento da produtividade agrícola nacional devido à agroindústria, ainda havia no Brasil cerca de 65 milhóes de pessoas em situação de insegurança 
alimentar, o que correspondia a um terço de toda a população. Tal contradição entre a alta produtividade agrícola e a insegurança alimentar justifica-se no fato de que o agronegócio atém-se às remunerações do mercado externo, do setor energético e de insumos agrícolas. Diante disso, constata-se que a maior parte dos alimentos consumidos pelos brasileiros é produzida por camponeses e pequenos agricultores, quem mais têm se prejudicado com o adoção do modelo do agronegócio. Os bens do agronegócio servem para equilibrar a balança comercial brasileira, pois são em sua maioria destinados à exportação. (CLEMENTS; FERNANDES, 2012, p. 22)

A entrada do agronegócio no Brasil, em um momento histórico em que a participação democrática era criminalizada pelo Estado. Isso significou a possibilidade de crescimento econômico, cujos benefícios foram privatizados, e de destruiçáo socioambiental, cujos prejuízos foram socializados. A entrada do agronegócio em Moçambique segue o mesmo roteiro de baixa participação democrática e a adoção de um modelo que atende a uma pequena e privilegiada parcela da população local em detrimento dos interesses da maioria. Os camponeses de Moçambique, como seus congêneres brasileiros, tendem a seguir o mesmo caminho, qual seja, a exclusão de qualquer benefício econômico que o modelo do agronegócio propóe e sua inclusão em todos os prejuízos sociais e ambientais.

Além disso, o que torna ainda mais perverso o sistema do Prosavana para Moçambique é o fato de que não lhe foi dada a oportunidade de participar ativamente de sua construção. A situação de Moçambique hoje pode ser considerada pior do que a do Brasil nos anos de 1970, pois neste caso houve a negociaçáo direta e a celebração de um acordo bilateral de cooperação Norte-Sul, entre Brasil e Japão, em que ambas as partes puderam defender seus interesses nacionais. Já no caso do Prosavana, o acordo internacional trilateral é travestido de cooperação Sul-Sul e desenvolveu-se à margem dos interesses do país africano. A participaçáo do Brasil na materialização da cooperaçáo (Norte)-Sul-Sul em Moçambique tem sido fundamental. Por conta de ser visto como legitimador de uma simulação, o Brasil tem sido alvo de boa parte das críticas referentes ao Prosavana.

Na imprensa de Moçambique são publicados artigos contrários à presença do Brasil no país. Em 23 de agosto de 2011, por exemplo, o jornal O País publicou uma reportagem intitulada $O$ neocolonialismo brasileiro em Moçambique, na qual o autor elenca todos os impactos negativos da implementaçáo do Prodecer no Brasil, programa que tem sido universalmente propagado como o modelo para o Prosavana. Discorre o autor, na matéria, que o agronegócio corresponde ao esgotamento dos recursos naturais, à utilização massiva de agrotóxicos, à inserção no meio ambiente de organismos geneticamente modificados, à degradação do solo e à concentração fundiária. Conclui ele então dizendo que:

"O neocolonialismo brasileiro em Moçambique certamente não contribuirá com o desenvolvimento socialmente justo deste país. Se, por um lado, o Brasil pode oferecer conhecimento técnico para o cultivo de 
sementes na savana africana, por outro o país tem a oferecer um modelo insustentável de agronegócio, baseado na monocultura, na degradação ambiental e na concentração de terras nas mãos de poucos." (RAFAEL, 2011 apud LIMA, J. D. F., 2012, p. 101)

A cooperação Sul-Sul pressupóe a horizontalidade de atuação de Estados em desenvolvimento. Ela só pode existir em um contexto democrático onde as decisóes são tomadas em conjunto. A imposição de um modelo desenvolvido sem a participação de um dos pólos do acordo não é exemplo de horizontalidade. Pelo contrário, caracteriza-se por ser o retrato da verticalidade táo criticada nos modelos de cooperação Norte-Sul. A imposição de um modelo construído em consonância com os interesses de Estado do Norte desatende um dos requisitos fundamentais da cooperação Sul-Sul, que é a instituição de mecanismos internacionais sem a influência dos interesses dos países desenvolvidos. Por isso que se defende que o Prosavana não é um programa de cooperação Sul-Sul, mas (Norte)-Sul-Sul.

Por esse motivo, o Prosavana tem sido visto como um exemplo de uma nova espécie de colonialismo, que procura atender a demanda externa por recursos naturais em associação com a expansão de oportunidades econômicas para agentes que não se identificam com a sociedade local. Esta nova espécie de colonialismo enfraquece quem está fraco e fortalece quem é forte, o que contradiz o princípio da igualdade previsto no modelo de cooperação Sul-Sul. Os eventuais e limitados benefícios econômicos percebidos por esses Estados mais frágeis são direcionados às elites locais, que os monopolizam por meio de prática ilegais ou antidemocráticas. (SCOONES; CABRAL; TUGENDHAT, 2013, p. 3)

\section{Prosavana Funda-se em Ação Sem Demanda}

Outro desvio importante a ser melhor retratado como crítica ao caráter (Norte)Sul-Sul do Prosavana refere-se a ausência de participação ativa por parte de Moçambique, no exercício de sua capacidade jurídica internacional. Como foi visto anteriormente, a cooperação de tipo Sul-Sul defendida pelo Brasil pressupóe uma ação sob demanda, isto é, o Brasil só poderia agir internacionalmente dentro dos limites da provocação exercida de forma expressa, livre e soberana por outro Estado em desenvolvimento.

Durante o planejamento do Prosavana, Moçambique não participou das negociaçôes internacionais. A fase inicial do programa foi realizada através de um acordo bilateral entre Japão e Brasil. Moçambique foi escolhido posteriormente como base territorial de aplicação do projeto. Moçambique só foi procurado para integrar o acordo de cooperação internacional, depois que o programa estava completamente formatado, isto é, depois que Brasil e Japão já haviam decidido explorar economicamente a Savana. Pode-se, desta forma, associar esta espécie de acordo internacional com os contratos de adesão, cuja principal 
característica é a impossibilidade de discussão prévia de suas cláusulas por um dos contratantes, confundido com a parte mais frágil da relação jurídica, como bem demonstra a doutrina do Direito do Consumidor. Como nesses contratos de adesão, o Prosavana foi um acordo internacional imposto à parte mais frágil, sem a possibilidade discussão prévia de seu conteúdo. De todos os países que possuíam a Savana em seu território, Moçambique foi escolhido com base em estatísticas da FAO. (OKADA, 2014, p. 22)

Em resumo, a Moçambique foi oferecido um programa bilateral de utilização agrícola da Savana, cujo desenvolvimento e elaboração não contou com sua participaçáo direta em qualquer das etapas. Logo, o Prosavana não surgiu a partir de uma demanda de Moçambique. O Brasil, diferentemente do que estabelece o princípio da ação sob demanda, não se manteve em repouso, inerte, aguardando a provocação de Moçambique, um Estado em desenvolvimento, para o estabelecimento futuro de uma cooperação Sul-Sul. Pelo contrário, o Brasil agiu em consonância com o Japão, um Estado do Norte, de forma a moldar um instrumento que seria, em seguida, oferecido a Moçambique, com o intuito de consolidar uma cooperação (Norte)-Sul-Sul.

O que torna ainda mais frágil a defesa do caráter horizontal do Prosavana é o fato de que, segundo a doutrina, ter sido do governo japonês, representado pela JICA, a iniciativa de se criar o Prosavana. A vontade original, que proporcionou todos os desdobramentos jurídicos internacionais posteriores, encontra-se no Japão que, em vista o sucesso econômico do Prodecer, apresentou, em abril de 2009, por intermédio do PPJB, a proposta ao Brasil, consistindo no desenvolvimento a partir de então de um programa agrícola a ser implementado na África com o intuito de equilibrar a tensa relação entre oferta e demanda globais por alimentos. Diante das possibilidades de ganho diplomático e empresarial, o Brasil concordou em iniciar as discussóes que deram origem ao programa bilateral de exploração da Savana. De fato, em 3 de abril de 2009, houve a assinatura de um acordo entre JICA e ABC, pelo qual se confirmava o interesse recíproco em utilizar a estrutura do PPJB para a construçáo de um projeto de desenvolvimento da Savana africana. Ao fim, necessitava-se da base territorial onde a ideia seria materializada. Neste momento, munidos dos dados da FAO, Japão e Brasil decidiram procurar Moçambique, cujo consentimento soberano permitiu a formalização do acordo trilateral. Contudo, isso não impede a constatação de que o Prosavana é o resultado da participação exclusiva de Japão e Brasil. Moçambique apenas aderiu àquilo que foi decidido alhures, tornando lícita sua implementação em território moçambicano. (NOGUEIRA; OLLINAHO, 2013, p. 10)

Na verdade, na foi a demanda de Moçambique que retirou o Brasil do repouso para que houvesse o Prosavana, mas o Japão. Diante disso, houve a construçáo bilateral do programa. Quando Brasil e Japão demandaram a ação de Moçambique, não havia mais abertura para negociação. Se o propósito do Japão fosse tão somente a formalização de um acordo bilateral com o Brasil, não haveria nada de anormal. A questão relevante aqui 
refere-se ao fato de que, a partir do momento em que o Brasil colocou-se em marcha para a realizaçáo do Prosavana, sua atitude diante de Moçambique náo se caracterizou por ser uma ação sob demanda, conforme os critérios de realização da cooperação Sul-Sul. Ao contrário, foi uma ação a ser materializada em Moçambique, mas sob demanda do Japão.

\section{Conclusões}

O Prosavana insere-se na lógica globalizante de transformação de toda a agricultura mundial em agronegócio. A África é considerada atualmente por diversas instituiçóes internacionais o foco territorial para onde deve se expandir a fronteira agroindustrial. Desta forma, multiplicam-se as propostas de cooperação internacional naquele continente, sejam elas de natureza agrícola, sejam de natureza energética, mineradora ou de infraestrutura. Justificados em uma lógica anticolonial, os Estados em desenvolvimento, membros do BRICS, têm adotado uma estratégia de aprofundamento das relaçóes bilaterais com Estados africanos. De fato, Índia, China e Brasil têm sido os protagonistas em mecanismos internacionais de cooperação em vista do desenvolvimento local. O Prosavana adéqua-se a este processo global de expansão do agronegócio na África, baseada na participação efetiva de Estados do Sul. Surge, a partir daí, a valorização dos instrumentos de cooperação Sul-Sul como alternativa aos tradicionais sistemas Norte-Sul, em que prevalecem estruturas verticais de cooperação. Em tese, o Prosavana deveria ser mais um exemplo desta cooperação Sul-Sul. Contudo, a participação efetiva e direta do Japão no desenvolvimento do programa junto com o Brasil e sua posterior oferta a Moçambique evidencia as contradiçóes do processo de formação e aplicação do programa. Diferentemente do que se prevê no formato ideal da cooperação Sul-Sul, o Prosavana é um programa bilateral implementado trilateralmente em Moçambique. Japão e Brasil instituíram um projeto que foi oferecido e aceito por Moçambique. Faltam ao Prosavana elementos fundamentais da cooperação Sul-Sul, quais sejam, a horizontalidade, a exclusividade subjetiva, a participação democrática, a ação sob demanda. A ausência desses elementos faz com que o Prosavana seja um instrumento de cooperação (Norte)-Sul-Sul.

\section{Referências}

ABREU, Fernando José Marroni de. "A evolução da Cooperação Técnica Internacional no Brasil”. Mural Internacional, vol. 4, n. 2, jul-dez 2013, pp. 3-16.

AVELHAN, Lívia Liria. A presença brasileira na África: um estudo sobre o Programa Embrapa-Moçambique. Monografia submetida ao curso de Relaçóes Internacionais da Universidade Federal de Santa Catarina. Florianópolis, 2013.

CABRAL, Lídia; SHANKLAND, Alex; FAVARETO, Arilson; VAZ, Alcides Costa. "Brazil-Africa Agricultural Cooperation Encounters: Drivers, Narratives and Imaginaries of Africa and Development”. IDS Bulletin, 44.4, 2013. 
CABRAL, Lídia; SHANKLAND, Alex. "Narratives of Brazil-Africa Cooperation for Agricultural Development: New Paradigms?”. China and Brazil in African Agriculture (CBAA) Project, Working Paper 51, Future Agricultures Consortium, March 2013, pp. 1-27.

CHICHAVA, Sérgio; DURAN, Jimena; CABRAL, Lídia; SHANKLAND, Alex; BUCKLEY, Lila; LIXIA, Tang; YUE, Zhang. "Chinese and Brazilian Cooperation with African Agriculture: The case of Mozambique”. China and Brazil in African Agriculture (CBAA) Project, Working Paper 49, Future Agricultures Consortium, March 2013, pp. 1-29.

CINTRA, Luiz Antonio. “O mundo é para poucos”. Carta Capital. 06 fev. 2014. http:// www.cartacapital.com.br/revista/784/o-mundo-e-para-poucos-9774.html

CLASSEN, Sayaka Funada. Análise do Discurso e dos Antecedentes do Programa ProSAVANA em Moçambique - enfoque no papel do Japão. Tóquio: 20 jan. 2013. http://www.open.ac.uk/technology/mozambique/sites/www.open.ac.uk. technology.mozambique/files/files/Análise\%20do\%20Discurso\%20do\%20ProSAVANA\%20(Funada).pdf

CLEMENTS, Elizabeth Alice. "A territorialização do agronegócio e da agricultura camponesa/familiar em Moçambique: paradigmas, políticas e estratégias do modelo brasileiro para o desenvolvimento territorial rural”. Anais do VII Congresso Brasileiro de Geógrafos. Associação dos Geógrafos Brasileiros. Vitória: 10-16 ago. 2014.

CLEMENTS, Elizabeth Alice; FERNANDES, Bernardo Mançano. "Estrangeirização da terra, agronegócio e campesinato no Brasil e em Moçambique”. Observador Rural (OMR), Documento de Trabalho, n. 6, mai. 2013.

CLEMENTS, Elizabeth Alice; FERNANDES, Bernardo Mançano. Land Grabbing, Agribusiness and the Peasantry in Brazil and Mozambique. Paper presented at the International Conference on Global Land Grabbing II, October 17-19, 2012, organized by the Land Deals Politics Initiative (LDPI) and hosted by the Department of Development Sociology at Cornell University, Ithaca, NY.

EKMAN, Sigrid-Marianella Stensrud; MACAMO Carmen Stella. Brazilian Development Cooperation in Agriculture: A Scoping Study on ProSavana in Mozambique, with Implications for Forests. Center for International Forestry Research, Working Paper 138. Bogor: CIFOR, 2014.

FERNÁNDEZ, Antonio João Castrillon. Do Cerrado à Amazônia: as estruturas sociais da economia da soja em Mato Grosso. Tese submetida ao Programa de PósGraduação em Desenvolvimento Rural da Faculdade de Ciências Econômicas da UFRGS. Porto Alegre: Universidade Federal do Rio Grande do Sul, 2007. 
FINGERMANN, Natalia N. "Os mitos por trás do ProSAVANA". IDeIAS: Informação sobre Desenvolvimento, Instituiçóes e Análise Social, Boletim 49. Maputo: Instituto de Estudos Sociais e Econômicos, 2013, pp. 1-2.

FINGERMANN, Natalia Noschese. A cooperaçáo trilateral brasileira em Moçambique: Um estudo de caso comparado: o ProAlimenTOS e o ProSAVANA. Tese apresentada à Escola de Administração de Empresas de São Paulo da Fundação Getúlio Vargas. São Paulo, 2014.

LIMA, José Diniz Ferreira de. A ABC e a Embrapa na África, parceria na cooperação técnica: o caso de Moçambique. XIII Curso de Especialização em Relaçóes Internacional. Instituto de Ciência Política e de Relações Internacionais. Brasília: Universidade de Brasília, 2012.

LIMA, Melina Moreira Campos. Horizontalização da política externa brasileira no século XXI: um estudo das atuaçóes da EMBRAPA e da FIOCRUZ na África. Rio de Janeiro: UFRJ/IE, 2012.

MATURANA, Vivilaine. "Reflexóes acerca da relação entre a alimentação e o homem". Revista IGT, v. 7, n. 12, 2010, pp. 176-219. http://www.igt.psc.br/ojs ISSN 1807 $-2526$.

MONTEIRO, Tânia. "Lula aprova anúncio da Vale de doação a Moçambique”. Agência Estado. 10 nov. 2010. http://www.estadao.com.br/noticias/geral,lula-aprova-anuncio-da-vale-de-doacao-a-mocambique,638008,0.htm

NOGUEIRA, Isabela; OLLINAHO, Ossi. From Rhetoric to Practice in South-South Development Cooperation: A case study of Brazilian interventions in the Nacala corridor developement program. Working Paper, August 2013, Institute of Socioeconomics, University of Geneva.

OKADA, Kana. Role of Japan in Offshore Agricultural Ivestment: Case of ProSAVANA Project in Mozambique. Research Paper. The Hague: International Institute of Social Studies, 2014.

PINO, Bruno Ayllón. A cooperação triangular e as transformaçóes da cooperação internacional para o desenvolvimento. Texto para discussão. Brasília, Rio de Janeiro: IPEA, 2013.

RAFAEL, Adelson. "O neocolonialismo brasileiro em Moçambique”. Instituto Humanitas Unisinos. 25 ago. 2011. http://www.ihu.unisinos.br/noticias/46703-o-neocolonialismo-brasileiro-em-mocambique-

SCHLESINGER, Sergio. Cooperação e investimento do Brasil na África: O caso do ProSavana em Moçambique. Maputo: FASE, 2013. 
SCHLESINGER, Sergio. "Brazilian cooperation and investment in Africa: the case of ProSavana in Mozambique”. TEMTI Series of Economic Perspectives on Global Sustainability, EP 01-2014, TEMTI - CEESP/UICN, pp. 1-31.

SCOONES, Ian; CABRAL, Lídia; TUGENDHAT, Henry. "New Development Encounters: China and Brazil in African Agriculture”. IDS Bulletin, 44.4, 2013, pp. $1-19$.

THE INTERNATIONAL BANK FOR RECONSTRUCTION AND DEVELOPMENT/THE WORLD BANK. Awakening Africa's Sleeping Giant: Prospects for Commercial Agriculture in the Guinea Savannah Zone and Beyond. Washington: The World Bank, 2009.

TORRES, Alcides. "Revisão para baixo dos estoques norte-americanos de milho”. Canal Rural. 12 fev. 2015. http://blogs.canalrural.com.br/blogdoscot/2015/02/12/revisao-para-baixo-dos-estoques-norte-americanos-de-milho/ 